How to cite: Kholiavchuk, D., Cebulska, M. (2021) Precipitation Shortage in the High Ukrainian and Polish Carpathians. 2021 "Air and Water - Components of the Environment" Conference Proceedings, Cluj-Napoca, Romania, p. 33-42, DOI: 10.24193/AWC2021_04.

\title{
PRECIPITATION SHORTAGE IN THE HIGH UKRAINIAN AND POLISH CARPATHIANS
}

\author{
Dariia KHOLIAVCHUK ${ }^{1}$, Marta CEBULSKA ${ }^{2}$ \\ DOI: 10.24193/AWC2021_04
}

\begin{abstract}
In the recent decades, droughts and dry episodes throughout a year have become common for both arid and humid regions. The Carpathian Mountains referred to as natural water towers are also the case. Accordingly, the study aims and distinguishing monthly and daily patterns and peculiarities of precipitation shortage in the high-mountain areas (above $1000 \mathrm{~m}$ ) of the Polish and the Ukrainian Carpathians using monthly and daily data series (1984-2015) of weather stations Kasprowy Wierch (1991 m a.s.1), Dolina Pięciu Stawów (1670 m a.s.l) and Morskie Oko (1408 m a.s.l) in the Polish Carpathians, Play (1343 m a.s.l) and Pogegevskaya (1429 m a.s.l) in the Ukrainian Carpathians. Here, in all the months throughout a year, dry episodes have been detected. In the Polish Carpathians, represented by three measuring stations, the driest episodes in the years took place from August to October and January, and slightly less - about $11-16 \%$ in the remaining months. In the monthly context, the highest frequency of dry months, exceeding $20 \%$, is detected in June both in Pogegevskaya, as well and in April and July in Play. In March, April, as well as November extreme atmospheric drought took place in the entire area of the Polish Tatra Mountains, the highest mountain range of the Polish Carpathians. In all the measuring stations of the area in November 2011, the precipitation amount did not exceed $11 \mathrm{~mm}$. They accounted for less than $10 \%$ of the average multiannual precipitation sum. Alongside, the positive trend in the years from 1984 to 2015 with significance levels of 0.1 and 0.2 was only established in the lowest monthly precipitation sums at Pogegevskaya. The longest episodes without precipitation, periods that begin and end with a day without precipitation, are detected in most parts of the study area in October and November 2011, especially in the western and southern parts of the Polish Carpathians.
\end{abstract}

Keywords: atmospheric droughts, periods without precipitation, Standardized Precipitation Index, extremely dry periods, Carpathians

\section{INTRODUCTION}

The shortage of precipitation is a natural feature of climate, which in turn is caused by the long-term deficit. Due to the fluctuations and variability of precipitation, especially in the area, the identification of periods with a shortage of

\footnotetext{
${ }^{1}$ corresponding author, Yuriy Fedkovych Chernivtsi National University, Department of Physical Geography, Geomorphology, and Paleogeography, 2 Kotsubynskyi Street, 58012, Chernivtsi, Ukraine, d.kholyavchuk@chnu.edu.ua

${ }^{2}$ Cracow University of Technology, Faculty of Environmental and Power Engineering, Department of Geoengineering and Water Management 24 Warszawska Street, 31-155, Cracow, Poland, marta.cebulska@pk.edu.pl
} 
precipitation should be carried out considering the local characteristics of the area (EDO, 2017).

The deficit of precipitation is supported by high air temperature, high insolation, as well as low air humidity (De Bono et al., 2004; Rebetez et al., 2006). The effects of drought in the area are not only socio-economic, but also environmental. According to research by Hanel et al. (2018), extreme droughts that hit Europe in 2003 and 2015 (Ionita, 2017) were caused by the precipitation and high air temperature. Long-lasting precipitation deficit may result in the development of subsequent phases of drought, including soil and even hydrological drought (Łabędzki, 2006; Mishra and Singh, 2010). In the years of 1994-2004 most of the droughts took place in Bosnia and Herzegovina - 3, and in Croatia and Spain - 2 (Bartkiewicz et al. 2005). Further intensification of hot and dry periods, particularly severe in southern Europe, the northern coast of France and the southern part of the British Isles is expected (Bartkiewicz et al. 2005; Przymusinska et al. 2004). Besides, the results of the research by Spinoni et al. (2020) based only on atmospheric precipitation, indicate that about $15 \%$ of the Earth's surface will probably experience more frequent and severe droughts in the years 2071-2100 compared to the period 1981-2010. On the other hand, using precipitation and air temperature for medeling droughts, Spinoni et al. (2020) predict more frequent and severe droughts in South America, the Mediterranean region, South Africa, Southeast China, Japan, and South Australia. The evidence of the atmospheric drought occurrence with catastrophic effects with not only in Europe but also in other countries are found numerous scientific works, including Fink et al. (2004), VicenteSerrano et al. (2012), Spinoni et al. (2013); Vido et al. (2015); Brazdil et al. (2015); Cebulska (2016, 2018); Spinoni et al. (2020).

In the light of the research conducted by Spinoni et al. (2015), the drought-prone areas in Europe have increased, while in Ukraine previous studies have not detected any trends in the drought intensity or distribution, especially in the mountainous areas (Cherenkova et al., 2015). However, in the Polish and Ukrainian Carpathians, periods of days without precipitation are found. The longest such period took place in October and November 2011 and lasted up to 40 days, covering western and southern parts of the Polish Carpathians (Cebulska, 2018).

Accordingly, the study concerns the assessment of the periods with a shortage of precipitation based on daily precipitation totals and monthly precipitation totals from the Polish and Ukrainian meteorological stations. In the case of daily precipitation totals, particular attention was paid to the periods without precipitation as well as the frequency of periods with insufficient precipitation. However, in the case of monthly precipitation totals, the severity of atmospheric drought is assessed considering the Standardized Precipitation Index (SPI) to detect dry periods.

\section{STUDY AREA, DATA AND METHODS}

The Polish and Ukrainian Carpathians are the area of research. The mountain range, located in Central and Eastern Europe, forms an arc about $1300 \mathrm{~km}$ long. The Polish Carpathians in particular stretch from west to east for $330 \mathrm{~km}$ covering 19,600 $\mathrm{km}^{2}$ which is about $6 \%$ of the country's area. Within them are the Polish Tatra 
Mountains with the highest peak - Rysy, $2499 \mathrm{~m}$ above sea level (Warszyńska, 1995). On the other hand, the Ukrainian Carpathians occupy $3.6 \%$ of the territory of Ukraine (Kovalchuk et al., 2012). Here, the area at altitudes higher than $1,000 \mathrm{~m}$ a.s.l., where the most precipitation occurs, makes up $9.2 \%$ of the Ukrainian Carpathians and remains controversial area regarding the precipitation variability (Kholiavchuk and Cebulska, 2019).

Accordingly, the variability of periods with precipitation deficit using the daily and monthly sums of precipitation for the years 1984-2015 at five measuring stations (Fig. 1) is addressed. In the area of the Polish Carpathians, three weather stations located above $1000 \mathrm{~m}$ above sea level located in Kasprowy Wierch, Dolina Pięciu Stawów and Morskie Oko are considered. In the Ukrainian Carpathians, two weather stations located in Play and Pogegevskaya are considered. Daily and monthly precipitation totals from measuring stations located in the Polish Carpathians were obtained from the Institute of Meteorology and Water Management - National Research Institute, while from the measuring stations in the Ukrainian Carpathians, they were obtained from the Central Geophysical Observatory of the State Emergency Service of Ukraine. In the case of daily precipitation totals, the study considers data from 1991-2015 from Dolina Pięciu Stawów, and from Play and Pogegevskaya stations from 1984-2010.

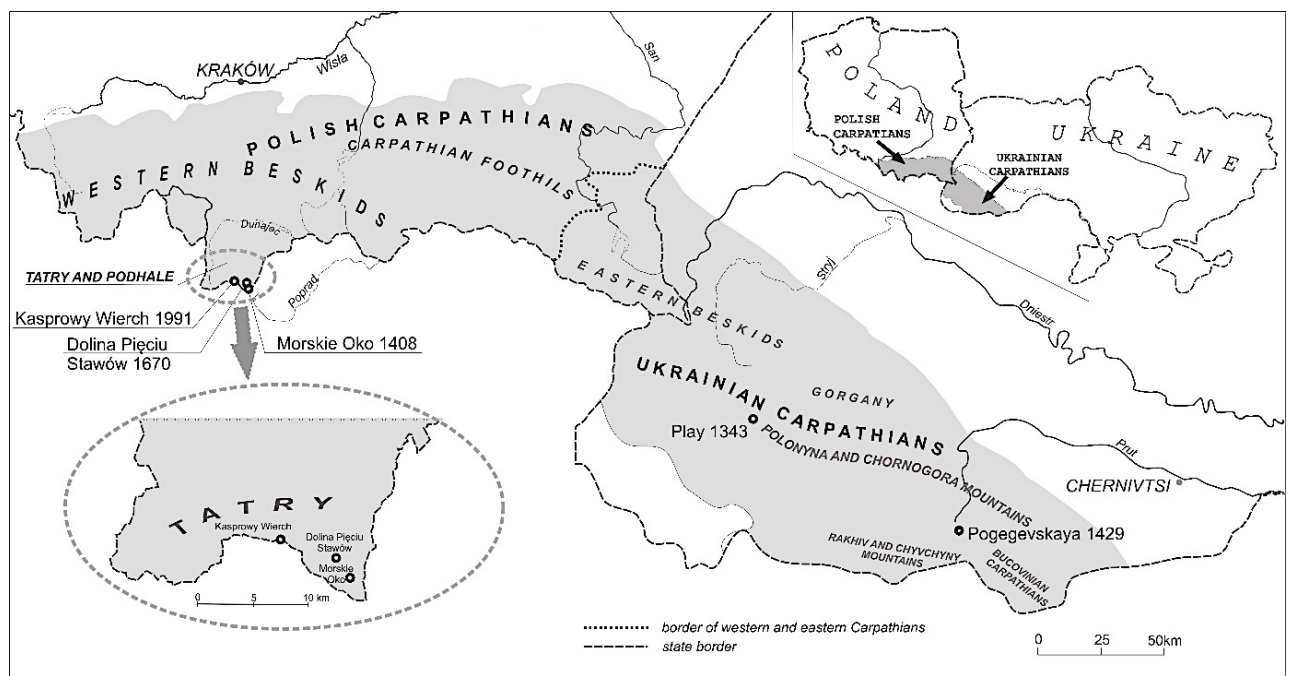

Fig. 1. Location of weather stations (the altitude of the station is given in brackets above sea level)

An important element in the assessment of meteorological drought is the analysis of the frequency of periods without precipitation as well as detection of the frequency of dry periods with different intensity. Based on the database of daily precipitation totals, the frequency of periods without precipitation different in duration is determined. Here, the series of days without precipitation begins and ends with the 
day in which no precipitation is detected are considered. The daily sums of precipitation are also analysed. For this purpose, the classification of daily precipitation was applied (Olechnowicz-Bobrowska, 1970; Twardosz, 2000; Cebulska, 2018), according to which the precipitation amount was considered insufficient when the total daily sum does not exceed $1 \mathrm{~mm}$. Considering common positive asymmetry and gamma distribution for precipitation sequence, transformation function for normalization procedure is applied (Labędzki, 2017).

Periods with the precipitation deficit are determined using the commonly used indicator for the identification of meteorological drought - the Standardized Precipitation Index (SPI) for one month (SPI-1) (McKee et al., 1993, 1995; Łabędzki, 2006, 2017; Hayes et al., 2011).

$$
S P I=\frac{f(P)-\overline{f(P)}}{d_{u}}
$$

where:

$f(P)=\sqrt[3]{P}-$ converted normalized sum of precipitation, $\mathrm{mm}$;

$\overline{f(P)}$ - the average value of normalized precipitation sequence, $\mathrm{mm}$;

$d_{u}$ - the standard deviation of normalized precipitation sequence, $\mathrm{mm}$.

An extremely dry period was considered one for which the value of the SPI index $\leq-2.0$, while the very dry period was considered one for which SPI is within the values $-2.0 \div-1.50$, and a moderately dry period when SPI $--1.50 \div-1.00$ (McKee et al., 1993, 1995).

\section{RESULTS AND DISCUSSION}

\subsection{The course of periods without precipitation and with insufficient precipitation}

On average, less than $47 \%$ of days without precipitation each year are detected in the study area. The most, $46.5 \%$ of the days on average, occurs at Morskie Oko, and the least $-30 \%$ at Pogegevskaya. Days with low or very low precipitation (0.1-1.0 $\mathrm{mm}$ ) at observed at each station, but the biggest number of the days occurred in the eastern part of the Carpathians (19\%), while in the area of the Polish Tatra Mountains their number did not exceed $15 \%$. Using the database of daily precipitation sums, the frequency of the sequence of days without precipitation of various duration (from 1 day to the longest period without precipitation) was determined. The period of days without precipitation begins and ends with a day in which no precipitation occurred. At each measuring station, the greatest number of days was single without rainfall (less than 7\%). Longer periods without precipitation occurred much less frequently. However, periods with days without precipitation lasting successively from 1 day to 14 days are detected at each weather station. Thus, the longer the period without precipitation, the lower its frequency. The periods with the duration over 15 days occur sporadically and not at all stations.

The longest periods without precipitation in the area ranged from 20 days at Kasprowy Wierch to 39 days in the Dolina Pięciu Stawów. At the weather stations 
Play and Pogegevskaya, the longest period without precipitation was 24 days at Play and 33 consecutive days at Pogegevskaya (Table 1).

Table 1. Number of consequent days without precipitation (year of occurrence is given in brackets)

\begin{tabular}{|c|l|c|c|c|}
\hline \multirow{2}{*}{ Station } & \multicolumn{4}{|c|}{ Number of consequent days without precipitation } \\
\cline { 2 - 5 } & $20-25$ & $26-30$ & $31-35$ & $36-40$ \\
\hline Play & $1(2000)$ & - & - & - \\
\hline Morskie Oko & $2(1984,1993)$ & 1 & 1 & - \\
& & $(2007)$ & $(2011)$ & \\
\hline Pogegevskaya & - & - & 1 & - \\
\hline $\begin{array}{c}\text { Dolina Pięciu } \\
\text { Stawów }\end{array}$ & $1(2011)$ & - & 1 & 1 \\
\hline Kasprowy Wierch & $1(2011)$ & - & - & - \\
\hline
\end{tabular}

All the stations are located above $1000 \mathrm{~m}$ above sea level, where high precipitation sums are common. However, even in such an area, prolonged periods without precipitation lasting more than 20 days are observed. They are characteristic of autumn in the different decades. In the Polish Tatra Mountains, November 2011, when the deficit of precipitation is noticed, deserves special attention (Cebulska and Twardosz 2010; Twardosz and Cebulska 2020). This period at Kasprowy Wierch lasted from November 6 to November 15, and at Morskie Oko from October 26 to November 29. At Pogegevskaya, the station located at an altitude of 1,429 $\mathrm{m}$ above sea level, the longest period lasted from September 24 to October 26, 2000.

\subsection{The course of meteorological drought periods}

All the weather stations are in the area with the highest monthly precipitation in the Polish and Ukrainian Carpathians. However, periods of low precipitation are also characteristic of these regions. In the entire study period, at each meteorological station, most of the detected dry periods are moderately dry (Table 2), and the least - extremely dry. The least of dry months (59) with different levels of drought intensity are detected at Play, the station located at an altitude of 1,343 $\mathrm{m}$ above sea level, while the most (65) - at Pogegevskaya stations and at Dolina Pięciu Stawów. At Kasprowy Wierch, the highest station in the research area, 10 extremely dry months occurred in the 32-year period. In the years 1984-2015, most of the dry months with different levels of drought severity took place in October (20\%). In the remaining months, the occurrence varies from $11 \%$ in November to $17 \%$ in September. At each station, on average, dry month with different levels of drought severity took place every three years. Most of the dry periods were moderately dry, for which SPI index is from -1.0 to -1.50 . 
Table 2. Number of dry months with different levels of drought severity

\begin{tabular}{|c|c|c|c|c|c|}
\hline $\begin{array}{c}\text { Drought } \\
\text { severity }\end{array}$ & Play & $\begin{array}{c}\text { Morskie } \\
\text { Oko }\end{array}$ & Pogegevskaya & $\begin{array}{c}\text { Dolina } \\
\text { Pięciu } \\
\text { Stawów }\end{array}$ & $\begin{array}{c}\text { Kasprowy } \\
\text { Wierch }\end{array}$ \\
\hline $\begin{array}{c}\text { Moderately } \\
\text { dry }\end{array}$ & 29 & 36 & 35 & 46 & 34 \\
\hline Very dry & 18 & 17 & 22 & 13 & 17 \\
\hline $\begin{array}{c}\text { Extremely } \\
\text { dry }\end{array}$ & 12 & 7 & 8 & 6 & 10 \\
\hline Sum & 59 & 60 & 65 & 65 & 61 \\
\hline
\end{tabular}

Alongside, not every month in the annual course was moderately dry. For example, such a period was not noticed in March at Kasprowy Wierch, in January and February, August and December at Play and April at Pogegevskaya. The highest number of moderately dry months in the entire study area occurred in July and October $-21(65.6 \%)$, and the least in November $-9(28 \%)$.

The highest number of very dry months, with SPI in the range $-1.5 \div-2.0$ in the area above $1000 \mathrm{~m}$ above sea level is $4(12.5 \%)$ in April in the Ukrainian Carpathians. At the other stations, the number of very dry months in the 32-year period was up to 3 in January, March, and May in the eastern part of the Carpathians, and in August, September and October in the western part. November was very dry only two times $(6.3 \%)$ and March -3 times $(9.4 \%)$.
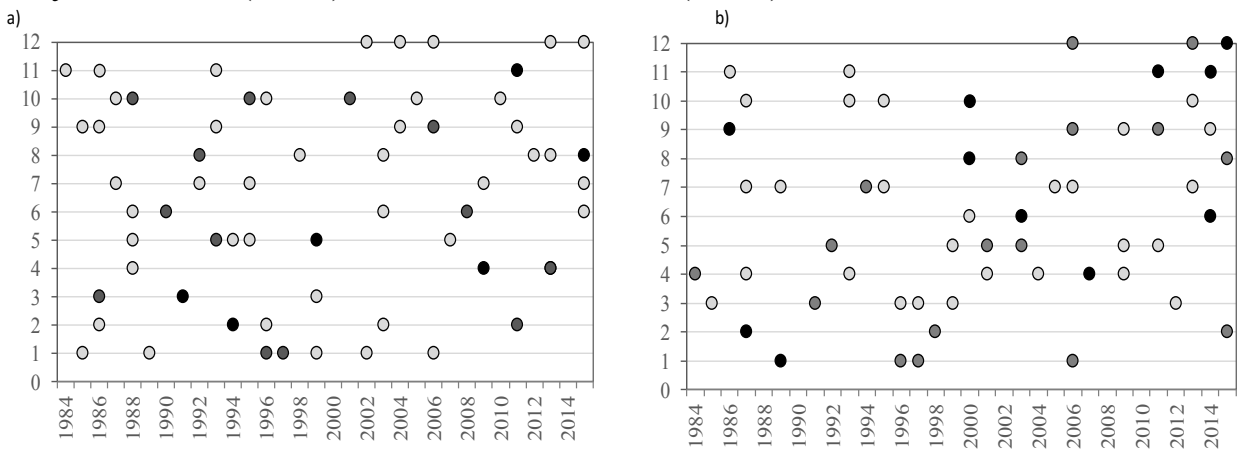

extremely dry $\bigcirc$ very dry $\bigcirc$ moderately dry

Fig. 2. Dry periods with different levels of drought severity: a) Dolina Pięciu Stawów, b) Play

Most of the very dry months occurred at separate stations (Table 3). Only in August and September, the drought affected 4 weather stations. This took place in August 2003 and September 2006. Both in August 2003 at Dolina Pięciu Stawów and in September 2006 at Pogegevskaya, the months were not very dry, but moderately dry. In the period from June to August 2003, many regions of Europe not only experienced the precipitation deficit, but the air temperature was $5^{\circ} \mathrm{C}$ higher 
than the average temperature in the years 1961-1990. Thus, the 2003 summer has become the warmest summer in this area since at least 1864 (Fink et al., 2004, De Bono et al. 2004). According to the research by Hanel et al. (2018), droughts in 2003 and 2015 caused by a significant precipitation deficit and high air temperature are considered the most extreme.

Table 3. Number of very dry months in the same year at weather stations

\begin{tabular}{|c|c|c|c|c|c|c|c|c|c|c|c|c|}
\hline $\begin{array}{c}\text { Number } \\
\text { of stations }\end{array}$ & I & II & III & IV & V & VI & VII & VIII & IX & X & XI & XII \\
\hline 1 & 1 & 4 & 3 & 2 & 5 & 3 & 3 & 4 & 3 & 3 & 2 & 3 \\
\hline 2 & 2 & 1 & - & 2 & 1 & - & - & 1 & - & 1 & - & 1 \\
\hline 3 & 1 & - & 2 & 1 & - & 1 & - & - & 1 & 1 & - & - \\
\hline 4 & - & - & - & - & - & - & - & 1 & 1 & - & - & - \\
\hline 5 & - & - & - & - & - & - & - & - & - & - & - & - \\
\hline
\end{tabular}

An extremely dry month is detected at least at one station throughout a year (Table 4). However, in January 1989, September 1986, and November 2014, an extreme drought occurred in the Ukrainian part of the Carpathians. Then, the monthly precipitation sum did not exceed $30 \%$ of the long-term average monthly sum. The lowest monthly precipitation in November $2014(9 \mathrm{~mm})$ is just about $8 \%$ of the long-term average monthly sum. In November 2011, extreme drought also occurred at all the stations (Table 4), when the monthly precipitation sum did not exceed $5 \%$ of the long-term average monthly sum at separate weather stations.

Table 4. Number of extremely dry months in the same year at weather stations

\begin{tabular}{|c|l|l|l|l|l|l|l|l|l|l|l|l|}
\hline $\begin{array}{c}\text { Number } \\
\text { of stations }\end{array}$ & I & II & III & IV & V & VI & VII & VIII & IX & X & XI & XII \\
\hline 1 & - & 3 & 1 & 2 & 2 & 4 & 1 & 2 & - & 1 & - & 1 \\
\hline 2 & 2 & 1 & 2 & - & - & - & - & - & 1 & 1 & 2 & - \\
\hline 3 & - & - & - & 1 & - & - & - & 1 & - & - & - & - \\
\hline 4 & - & - & - & - & - & - & - & - & - & - & - & - \\
\hline 5 & - & - & - & - & - & - & - & - & - & - & 1 & - \\
\hline
\end{tabular}

In the 32-year period, July 1990 at Morskie Oko was extremely dry according to the SPI classification. Then, the monthly precipitation was $45.4 \mathrm{~mm}$ (which is $29.9 \%$ of the long-term average). December 2015 also turned out to be an extremely dry month at Play. The monthly precipitation was $30.2 \mathrm{~mm}$, which is $24 \%$ of the longterm average. However, most of the extremely dry months occurred in November $7(22 \%)$. It is the only month when extremely dry conditions at least once a month are detected at each weather station e. August also turned out to be an extremely dry 
month at each weather station. It was August 2015in the western part, and August 2000 at Play and 1992 at Pogegevskaya in the eastern part of the Carpathians.

In the entire study area, the most severe atmospheric drought occurred in November 2011, when the SPI value ranged from -2.70 at Pogegevskaya to -3.89 at Morskie Oko. In November 2011, the meteorological drought covered the entire study area, when only the southern (Sa), western (Wa) and anticyclonic (Ka) types of atmospheric circulation dominated (Cebulska, 2018). At Pogegevskaya, meteorological drought of different levels of drought severity lasted up to four consecutive months - January, February, March, and April 1991. At the other stations, the drought covered two or even three consecutive months. In general, in the 32-year period, dry months with different degrees of drought severity occurred from August to December as well as in January and March (Table 5). Moreover, such periods occurred at four stations each month.

Table 5. Dry periods $(S P I<-1,0)$ that occurred at all the stations.

\begin{tabular}{|c|c|c|c|c|c|c|c|c|c|c|c|c|}
\hline Dry months & I & II & III & IV & $\mathrm{V}$ & VI & VII & VIII & IX & X & XI & XII \\
\hline $\begin{array}{c}\text { different } \\
\text { levels of } \\
\text { drought } \\
\text { severity }\end{array}$ & 亏 & - & $\bar{\Xi}$ & - & - & - & - & $\stackrel{\text { }}{\stackrel{\nu}{8}}$ & 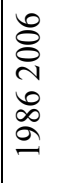 & $\stackrel{\infty}{\infty}$ & $\overline{\bar{D}}$ & ஓ̊ \\
\hline
\end{tabular}

\section{CONCLUSIONS}

1. Both in the Polish and Ukrainian Carpathians, in the 32 year-period, episodes without precipitation occurred at each measuring station, but with a different frequency. Among them single days without precipitation are the most frequent from $4.9 \%$ at Pogegevskaya to $6.7 \%$ at Kasprowy Wierch. The longer the period without precipitation, the less of such cases are noticed. Periods without precipitation lasting 7 days are noticed from 19 cases at Pogegevskaya to 45 cases at Morskie Oko. On the other hand, days without precipitation, lasting continuously 14 days are recorded at each station, but less than 5 cases. At the highest station Kasprowy Wierch the longest sequence of days without precipitation was 20 days. In the whole area, the number of days without precipitation did not exceed $50 \%$ in any of the meteorological stations.

2. In the whole area, insufficient precipitation with the total daily amount less than $1 \mathrm{~mm}$ occurred most often in the Ukrainian Carpathians - 19\%, while in the Polish Carpathians at Kasprowy Wierch $-14.5 \%$.

3. At each weather station throughout the entire study period most of the dry periods is moderately dry and the least - extremely dry months. The lowest number of dry months (59) with different drought intensity is noticed at Play, while the highest number is recorded at Pogegevskaya and Dolina Pięciu Stawów. At the highest station Kasprowy Wierch, 10 extremely dry months occurred in the 32-year period. 
4 At least one extremely dry month at each meteorological station is detected, but only in November 2011 an extreme drought at all the stations is observed. That was the month with the monthly precipitation sum less than $5 \%$ of the long-term average at separate meteorological stations.

\section{REFERENCES}

1. Brazdil R., Trnka M., Mikšovský J., Řezníčková L., Dobrovolný P. (2015), Spring summer droughts in the Czech Land in 1805-2012 and their forcings. International Journal Climatology, 35 (7), 1405-1421.

2. Bartkiewicz E., Leśny J., Radosław Juszczak R. (2005), Extreme hydrometeorological events in Europe in year 1994-2004. Water-Environment-Rural Areas, t. 5 z. 14, 29-44.

3. Cebulska M., Twardosz R. (2010), Temporal variability of the lowest monthly precipitation in the Upper Vistula River. Przeglad Geofizyczny, LV, 3-4, pp.175-188. V. 5. 1117-1130.

4. Cebulska M. (2016), Deficiencies of precipitation in the growing season in the Mała Wisła catchment (1984-2013). Acta Scientiarum Polonorum Formatio Circumiectus, 15(2): 13-26 (in Polish).

5. Cebulska M. (2018), Periods without precipitation and with low precipitation in the Polish Carpathians in the period from 1984 to 2015. Polish Journal of Agronomy, 34. pp.5261. DOI: 10.26114/pja.iung.355.2018.34.06.

6. Cherenkova E.A., Semenova I.G., Kononova N.K., Titkova T.B. (2015), Droughts and dynamics of synoptic processes in the south of the East European Plain at the beginning of the twenty-first century. Arid Ecosystems, 5(45). DOI: https://doi.org/10.1134/S2079096115020055.

7. De Bono A., Peduzzi P., Kluser S., Giuliani G. (2004), Impacts of Summer 2003 Heat Wave in Europe.

8. European drought observatory (EDO) (2017), What is drought? [online], URL: https://edo.jrc.ec.europa.eu/edov2/php/index.php?id=1001. Accessed on 16.12.2020

9. Fink A.H., et al. (2004), The 2003 European summer heatwaves and drought-synoptic diagnosis and impacts. Weather, 59 (8), 209-221.

10. Hanel M., et al. (2018), Revisiting the recent European droughts from a long-term perspective. Scientific Reports, 8 (1), 9499. DOI: https://doi.org/10.1038/s41598-018-274644, https://www.ecad.eu//indicesextremes /index.php.

11. Hayes M., Svoboda M., Wall N., and Widhalm M. (2011), The Lincoln Declaration on Drought Indices: universal meteorological drought index recommended. Bulletin of the American Meteorological Society, 92(4): 485-488. DOI: 10.1175/2010BAMS3103.1.

12. Ionita M., et al. (2017), The European 2015 drought from a climatological perspective. Hydrology and Earth System Sciences, 21, 1397-1419. DOI: https://doi.org/10.5194/hess21-1397-2017

13. Kholiavchuk D., Cebulska M. (2019), The highest monthly precipitation in the area of the Ukrainian and the Polish Carpathian Mountains in the period from 1984 to 2013. Theoretical and Applied Climatology, 138, 1615-1628. DOI: https://doi.org/10.1007/s00704-019-02910-z. 
14. Kovalchuk I., Kravchuk Ya., Mykhnovych A., Pylypovych O. (2012), Recent landform evolution in the Ukrainian Carpathians. In: Lóczy D, Stankoviansky M, Kotarba A (eds) Recent Landform Evolution. Springer Geography. Springer, Dordrecht, pp 177-204. DOI: 10.1007/978-94-007-2448-8_2.

15. Łabędzki L. (2006), Agricultural droughts an outline of problems and methods of monitoring and classification. Institute for Land Reclamation and Grassland Farming. Falenty.107. (in Polish).

16. Łabędzki L. (2017), Categorical Forecast of Precipitation Anomaly Using the Standardized Precipitation Index SPI. Water, 9(1):8. DOI: https://doi.org/10.3390/w9010008

17. McKee T.B., Doesken N.J., Kleist J. (1993), The relationship of drought frequency and duration to time scales. Proc. $8^{\text {th }}$ Conf. Applied Climatology, California, 179-184.

18. McKee T. B., Doesken N. J., Kleist J. (1995), Drought monitoring with multiple time scales. Preprints $9^{\text {th }}$. Conference of Applied Climatology, Dallas 15-20.01.1995 [online], URL: http://ccc.atmos.colostate.edu/relationshipofdroughtfrequency.pdf Accessed on 10.01.2021.

19. Mishra A.K., Singh V.P. (2010), A review of drought concepts. Journal of Hydrology, 391 (1), 202-216. DOI: https://doi.org/10.1016/j.jhydrol.2010.07.012

20. Olechnowicz-Bobrowska B. (1970), Częstość dni z opadem w Polsce. Prace Geograficzne, nr 86, Warszawa. (in Polish).

21. Przymusinska I., Radziejewski M., Kundzewicz Z.W. (2004), Dry and warm spells in Europe, based on Hadrm3 precise results. Geophysical Research, Abstr. vol. 6 s. 1.

22. Rebetez M., Mayer H., Dupont O., Schindler D., Gartner K., Kropp J.P., Menzel A. (2006), Heat and drought 2003 in Europe: a climate. Annals of Forest Science, 63, 569577. DOI: 10.1051/forest:2006043.

23. Spinoni J., Antofie T., Barbosa P., Bihari Z., Lakatos M., Szalai S., Szentimrey T., Vogt J. (2013), An overview of drought events in the Carpathian Region in 1961-2010, Advances in Science and Research, 10(1), 21-32. DOI: 10.5194/asr-10-21-2013.

24. Spinoni J., Naumann G., Vogt J., Barbosa P. (2015), European drought climatologies and trends based on a multi-indicator approach. Global and Planetary Change, 127, 50-57. DOI: https://doi.org/10.1016/j.gloplacha.2015.01.012

25. Spinoni J., et al. (2020), Future Global Meteorological Drought Hot Spots: A Study Based on CORDEX Data. Journal of Climate. DOI: 10.1175/JCLI-D-19-0084.1. 3635-3660.

26. Twardosz R. (2000), Wieloletnia zmienność sum dobowych opadów w Krakowie w powiązaniu z sytuacjami synoptycznymi, Prace Geograficzne, zeszyt 105, Kraków.

27. Twardosz R., Cebulska M. (2020), Temporal variability of the highest and the lowest monthly precipitation totals in the Polish Carpathian Mountains (1881-2018). Theoretical and Applied Climatology, 140 , 327 - 341, DOI: 10.1007/s00704-019-03079-1.

28. Vincente-Serrano S M., Begueria S., Lorenzo-Lacruz J., Camarero J., Lopez-Moreno I., Azorin-Molina C., Sanchez-Lorenzo A. (2012), Performance of drought indices for ecological, agricultural, and hydrological applications. Earth Interactions, 16, 1-27. DOI: https://doi.org/10.1175/2012EI000434.1

29. Vido J., Tadesse T., Šustek Z., Kandrík R., Hanzelová M., Škvarenina J., Škvareninová J., Hayes M. (2015), Drought Occurrence in Central European Mountainous Region (Tatra National Park, Slovakia) within the Period 1961-2010. Advances in Meteorology, 248-728. DOI: 10.1155/2015/248728.

30. Warszyńska J., (red) (1995). The Polish Carpathians - nature, man and his activities. Uniwersytet Jagielloński, Kraków. 